\title{
Decolorization of triphenylmethane dyes using immobilized cells of bacterial consortium
}

\section{Tina M ukherjee ${ }^{1 *}$ and $M$ anas Das $^{2}$}

Scottish Church college, 1 \& 3 Urquhart Square, Kolkata-700006

Department of Chemical Engineering, University of Calcutta (Retd.)

\begin{abstract}
The use of freely suspended microbial cells for dye removal is limited owing to their inherent disadvantages such as clogging of cells, low mechanical strength of the biomass etc. Immobilized cells offer advantages over dispersed cells such as high cell density, strong endurance of toxicity for being high in numbers, lower operating costs, simple maintenance management and production of smaller residual sludge. In this study immobilized cell mass of a bacterial consortium, isolated from dye contaminated wastewater, was used to decolorize a mixture of triphenylmethane dyes: Malachite Green, Crystal violet and Basic Fuchsin. Among all the matrices studied calcium alginate showed maximum decolorization with immobilized biomass. Therefore, cells immobilized on calcium alginate matrix was considered for studying the removal of triphenylmethane dyes. Effects of various parameters viz. alginate concentration, bead size, bacterial cell numbers, initial dye concentration, time, $\mathrm{pH}$ and temperature were investigated in batch system. The optimum conditions for removal of the dyes were found to be $\mathrm{pH} 8$, temperature $37^{\circ} \mathrm{C}$, alginate concentration of $2 \%(\mathrm{w} / \mathrm{v})$, a cell concentration of $1 \times 10^{9} \mathrm{cells} / \mathrm{ml}$. The dye removal capacity of the immobilized cells decreased as the initial dye concentration increased.
\end{abstract}

Keywords: Triphenylmethane dyes, immobilization, decolorization

\section{Introduction}

Triphenylmethane dyes are used extensively in the textile industries for dyeing of nylon, polyacrylon nitrile, modified nylon, wool, silk and cotton [1]. Some of the triphenylmethane dyes

*Author for Correspondence. E-mail: tina.m@rediffmail.com

www. ijamicro.com 
are used in medicine and forensics as biological stains. Gasoline, paper and leather industries are the major consumer of triphenylmethane dyes. Triphenylmethane dyes are also one of the widely used dermatological agents [2]. Gentian Violet and Malachite Green have been used in topical application on domestic animals against various infections. These have been used effectively for controlling the fungal growth under varying conditions [3]. Gentian Violet has also been applied to poultry feed for controlling fungal contamination. Hence, human population gets directly or indirectly exposed to the dyes through their widespread therapeutic and commercial use.

However, studies confirmed the cytogenetic toxic nature of Gentian violet, which states that that this compound is a mitotic poison as well as a clastogen in vitro [2]. Its clastogenic properties were confirmed in five other different mammalian cell types. Gentian Violet has been regarded as biohazardous substance [3]. Most of the triphenylmethane dyes are animal carcinogens [4]. There are many instances in which researchers have found their acute toxicity against fishes and mammals. Based on research findings, malachite green had been found to cause carcinogenic symptoms on laboratory mice [5]. Malachite green showed toxicity to many fish species, even when used at recommended doses under different environmental conditions especially $\mathrm{pH}$ and temperature [6].

Traditional wastewater treatment facilities are, however, unable to completely remove commercial dyestuff including triphenylmethane dyes such as Crystal Violet, Malachite Green from contaminated wastewater, thus contributing to pollution of aquatic habitats. However, among all the processes used to treat effluent containing dyes, biological processes are getting more attention as they are cost effective, environment friendly and do not produce large amount of sludge $[7,8]$.

Use of immobilized biomass for decolorization of dyes is gaining more attention these days. In recent years, several studies have shown that the mechanism for the decolorization of dyes using immobilized microorganisms may include both biodegradation and adsorption [7, 9]. Verma et al. [10] studied immobilization of Phanerochaete chrysosporium (MTCC 787) over loffa sponge for efficient and repeated use of the biomass for removal of triphenylmethane dyes. Loffa sponge is an inert natural cellulosic fiber matrix, obtained from ripen fruits of Loffa cylendrica. Immobilization of the fungal biomass over the matrix improved efficiency of the biomass due to less dense fiber packing as compared to the free fungal biomass. Immobilized yeast Candida tropicalis grown on sugarcane bagasse extract medium, was employed to remove synthetic dye Basic Violet 3 by Charumathi and Das in 2010 [11].

In our study, six different bacterial cells isolated from dye contaminated wastewater were used as a bacterial consortium and immobilized on various matrices in order to find out the most suitable one and various parameters were optimized in batch system. 


\section{M aterials and methods}

\section{Dyes used}

Triphenylmethane dyes namely Malachite Green Oxalate (MG), Crystal Violet Chloride (CV) and Basic Fuchsin (BF) Chloride were procured from Merck, India. These dyes were mixed together in equal proportions to make a stock concentration of $500 \mathrm{mg} / \mathrm{L}$.

\section{Isolation, acclimatization and selection of the microorganisms}

Dye contaminated wastewater was collected from different places (Jaggubazar-Kolkata, Habra, Tentulia, Titagarh, and Sodepur- North 24 Pgs, West Bengal - all small scale dying industries) and the samples were used for isolating potent strains which can remove the triphenylmethane dyes, namely Malachite Green Oxalate, Crystal Violet Chloride and Basic Fuchsin Chloride [12]. The bacterial strains collected were grown and maintained in Nutrient Agar medium.

\section{Preparation of medium for growth and removal study}

Mineral salt medium composition for growth and removal studies consist of $(\mathrm{g} / \mathrm{L}): \mathrm{KCl}-0.5$, $\mathrm{NaNO}_{3}-2, \mathrm{MgSO}_{4}, 7 \mathrm{H}_{2} \mathrm{O}-0.5, \mathrm{FeSO}_{4}, 7 \mathrm{H}_{2} \mathrm{O}-0.01$ and $\mathrm{MG}, \mathrm{CV}, \mathrm{BF}$ of varying amounts $(0.05-0.5$ $\mathrm{g} / \mathrm{L})$.

\section{Organisms}

Six different highly tolerant bacterial strains to TMR dyes were isolated and grown in mineral salt medium containing dye mix for $24 \mathrm{hr}$. The bacterial strains were determined by HiMedia DT 005, DT 011 identification discs and DT012 identification discs and were found to be E. coli, Staphylococcus aureus, Pseudomonas aeruginosa, Bacillus subtilis, Klebsiella pneumoniae and Enterobacter asburiae. In $50 \mathrm{ml}$ Mineral salt medium containing dyes $0.5 \mathrm{ml}$ of each of the bacterial strains was added (approximately $0.8 \times 10^{9}$ cells $/ \mathrm{ml}$ ). Biomass was harvested by centrifugation at $8000 \mathrm{rpm}$ for $10 \mathrm{~min}$. After washing with normal saline the required amount of biomass was used for immobilization.

\section{Immobilization of biomass}

\section{a. Immobilization on C arboxymethyl cellulose (C M C)}

$3 \% \mathrm{CMC}$ solution mixed with bacterial suspension at a concentration of about $1 \times 10^{9} \mathrm{cells} / \mathrm{ml}$. The CMC-bacteria mixture was injected using a hypodermic syringe drop-wise to $\mathrm{FeCl}_{3}$ solution $(0.05 \mathrm{M})$ to form beads. The beads entrapped with bacterial cells (immobilized) were cured in the $\mathrm{FeCl}_{3}$ solutions for $1 \mathrm{hr}$ to enhance their mechanical stabilities. Diameter of beads varied from 2 $5 \mathrm{~mm}$.

\section{b. Immobilization on C alcium alginate}

Sodium alginate solution (3\%) of $6 \mathrm{ml}$ was mixed with $3 \mathrm{ml}$ bacterial suspension in normal saline at a concentration of about $1 \times 10^{9}$ cells $/ \mathrm{ml}$. The Sodium alginate bacteria mixture was gently 
dropped into $0.2 \mathrm{M} \mathrm{CaCl}_{2}$ solution using a hypodermic syringe allowing beads to be formed. The diameter of the beads ranged from $2-5 \mathrm{~mm}$. The beads were cured in $0.2 \mathrm{M} \mathrm{CaCl}_{2}$ solution for 2 $\mathrm{hr}$ to enhance their mechanical stabilities.

\section{c. Immobilization on A gar and agarose}

$4.5 \%$ agar solution was prepared by dissolving required amount of agar in distilled water by boiling. Then $6 \mathrm{ml}$ of $4.5 \%$ agar solution at $42^{\circ} \mathrm{C}$ was mixed with $3 \mathrm{ml}$ normal saline solution containing $1 \times 10^{9}$ cells $/ \mathrm{ml}$. After solidification of the agar, $3 \times 3 \times 3 \mathrm{~mm}^{3}$ cubes were cut and washed with normal saline. Same procedure was followed with $4.5 \%$ agarose solution as matrix instead of agar.

\section{Decolorization of dye mix using immobilized cells of bacterial consortium}

For decolorization study, immobilized cells were added to $50 \mathrm{ml}$ of dye containing mineral salt medium in $100 \mathrm{ml}$ Erlenmeyer flask. After decolorization, the broth was centrifuged at $8000 \mathrm{rpm}$ for $10 \mathrm{~min}$. Clear supernatant was used for determination of dye removal in terms of $\%$ decolorization using UV-Visible spectrophotometer (U-4100, Hitachi). MG, CV and BF in a single solution were scanned from $300-700 \mathrm{~nm}$, where from maximum absorption $\left(\lambda_{\max }\right)$ was obtained at $585 \mathrm{~nm}$. The $\%$ decolorization was calculated using the following expression:

$$
\% \text { decolorization }=[(\text { initial absorbance-observed absorbance }) / \text { initial absorbance }] \times 100
$$

Each experiment was conducted in triplicate and mean values were taken. For controls, samples containing no immobilized beads and sample containing no dye were run simultaneously with the experimental samples. The former control was given to see nonspecific dye removal by components in the medium, while the latter showed the growth of the bacterial strain in media lacking triphenylmethane dyes.

After selecting the suitable matrix for immobilization of the bacterial cells based on removal efficiency, it was used for further studies to obtain other parameters such as initial concentrations of dyes, contact time, $\mathrm{pH}$, temperature, alginate concentration and cell concentration in a $50 \mathrm{ml}$ TPM mineral salt medium and maintained at a rotation speed of $130 \mathrm{rpm}$.

\section{Results and discussion}

\section{Screening of different matrices for immobilization of bacterial consortium for dye removal}

The dye removal was conducted in batch process and the most suitable matrix to determine dye decolorization was screened. Various matrices viz. CMC, agar, agarose and calcium alginate were screened for the immobilization of bacterial consortium for effective entrapment and removal. Among all matrices tested, alginate showed highest dye removal efficiency $(89.2 \%)$ in this study followed by agar (85.4\%), CMC (76\%) and agarose (71\%) (Figure 1). 


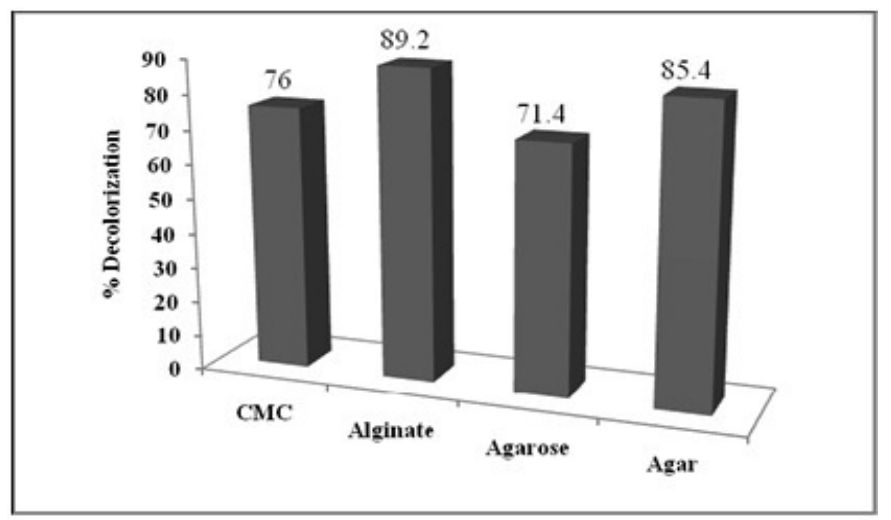

Figure 1. Screening of immobilization matrix for effective dye removal, initial dye concentration $50 \mathrm{mg} / \mathrm{L}$.

\section{Effect of Alginate concentration on dye removal}

The effect of sodium alginate concentration on immobilization was studied by varying the concentration from $1 \%$ to $5 \%$. To determine the optimum alginate concentration, in an $100 \mathrm{ml}$ Erlenmeyer flask $50 \mathrm{ml}$ Mineral salt medium was taken and approximately $1 \mathrm{gm}$ of alginate bead was added which contains $0.8 \times 10^{9}$ mixed bacterial cells per $\mathrm{ml}$ at a $\mathrm{pH}$ of 7 and a temperature of $35 \mathrm{C}$ for $24 \mathrm{hrs}$ under shaking condition at $130 \mathrm{rpm}$. Too low sodium alginate concentration resulted in very soft beads while sodium alginate concentration above $3 \%$ caused hardening of the beads creating diffusion problems. At high sodium alginate concentration $(>4 \%)$, efficiency dropped as the substrate has difficulty in diffusing through the beads. However, when only $1.0 \%$ sodium alginate concentration was used, the beads obtained were too soft and thus were easily broken because of their low mechanical strength resulting leakage of bacterial cells from the beads. Maximum dye removal was noted in case of $2 \%$ sodium alginate concentration when initial dye concentration was $50 \mathrm{mg} / \mathrm{L}$ (Figure 2).

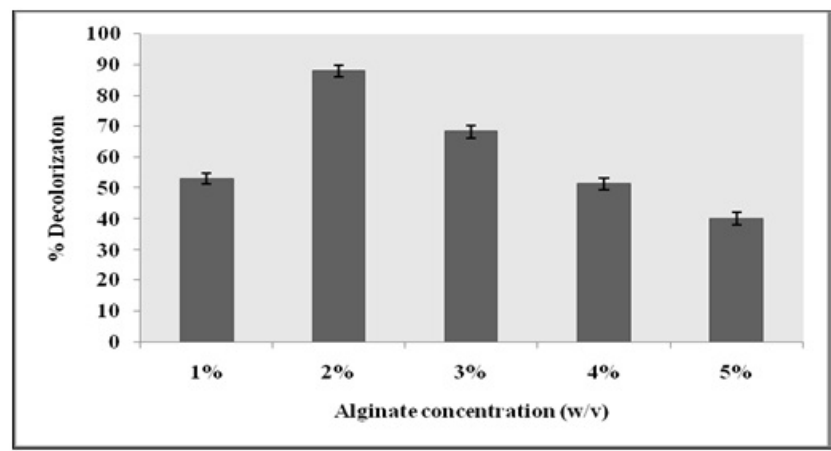

Figure 2. E ffect of alginate concentration on dye decolorization 


\section{Effect of cell concentration on removal}

The effect of cell concentration in immobilized beads was investigated by varying the cell concentration from $0.8 \times 10^{9}$ to $1.2 \times 10^{9}$ cells per $\mathrm{ml}$ of bacterial consortium. For determining the effect of cell concentration on dye decolorization, a $100 \mathrm{ml}$ Erlenmeyer flask containing $50 \mathrm{ml}$ Mineral salt medium containing TPM dyes was taken and approximately $1 \mathrm{gm}$ of alginate bead was added at a $\mathrm{pH}$ of 7 and a temperature of $35 \mathrm{C}$ for $24 \mathrm{hrs}$ under shaking condition at 130 $\mathrm{rpm}$. An increase in cell concentration increased the dye removal efficiency well up to the concentration of $1 \times 10^{9}$ cells per $\mathrm{ml}$ of culture (Figure 3). Further increase in cell concentration did not increase the dye removal efficiency. The dye removal efficiency remained almost unaffected by increase in cell numbers beyond $1 \times 10^{9}$ cells per $\mathrm{ml}$ of culture.

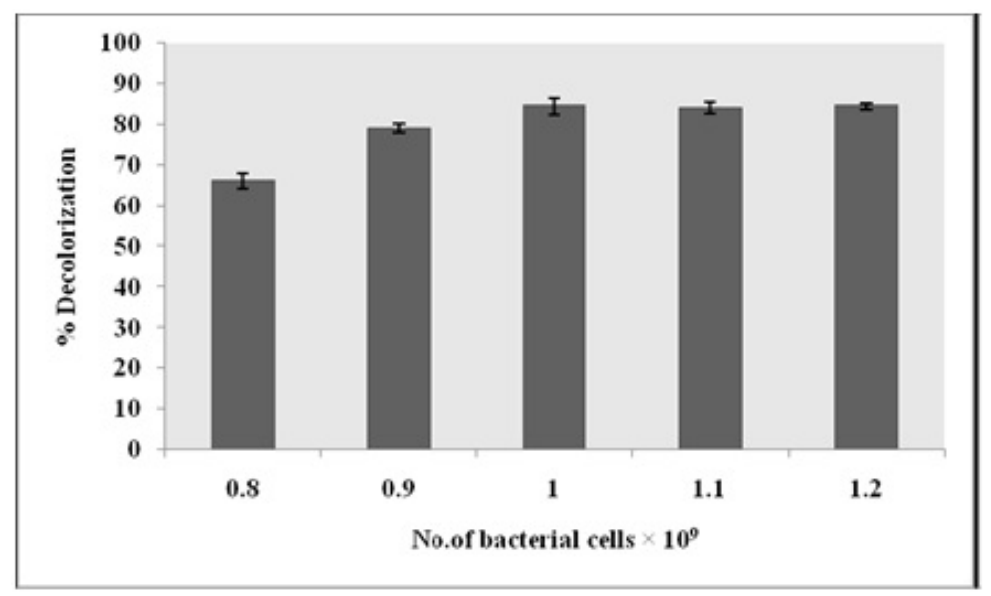

Figure 3. E ffect of cell count on dye decolorization

\section{Effect of initial dye concentration}

In order to study the effect of initial concentration of triphenylmethane dyes, the experiments were carried out at a cell concentration which contains approximately $1 \times 10^{9}$ bacterial cells $/ \mathrm{ml}$ of bacterial culture. In an Erlenmeyer vessel of $100 \mathrm{ml} 50 \mathrm{ml}$ mineral salt medium containing triphenylmethane dyes was taken and approximately $1 \mathrm{gm}$ of alginate bead was added at a $\mathrm{pH}$ of 7 and a temperature of $35 \mathrm{C}$ for $24 \mathrm{hrs}$ under shaking condition at $130 \mathrm{rpm}$.

Below this $50 \mathrm{mg} / \mathrm{L}$, dye decolorization was $100 \%$ in all the concentrations tested under the same condition. Figure 4 demonstrate the effects of initial dye concentration on decolorization. It was found that immobilized biomass was capable of decolorizing up to only $800 \mathrm{mg} / \mathrm{L}$. The decolorization at the lowest $(50 \mathrm{mg} / \mathrm{L})$ and highest dye concentration $(800 \mathrm{mg} / \mathrm{L})$ was $92 \%$ and $13.5 \%$, respectively. A number of studies have been carried out to determine the decolorization of various dyes with immobilized microorganisms. Very few reports are available that shows the decolorization of Triphenylmethane dyes with immobilized bacterial biomass. It has been stated by Chheriaa et al.(2012) that when Malachite Green and Crystal violet were treated separately by 
bacterial consortium they obtain $99 \%$ and $91 \%$ decolorization respectively when used at a concentration of $50 \mathrm{mg} / \mathrm{L}$ [13]. In this study while we use the immobilized biomass at $50 \mathrm{mg} / \mathrm{L}$ of mixed dye concentration, (they were not used separately, they were used in a mixed solution) we also obtain a good amount of decolorization $(92 \%)$. Another study made by Chen et al. [14] used Polyvinyl alcohol immobilized microorganisms and obtain good decolorization efficiency (75\%) for an azo dye RED RBN, here also a single dye sample was used.

In our study we used immobilized bacterial consortium to determine the decolorization of mixed dye solution, where we also obtain good decolorization at lower concentrations of dyes which gets reduced at higher dye concentration. Under immobilized condition, as the organisms are trapped into alginate beads they were not capable of multiply and increase their numbers. Therefore, although the dye concentrations increase, due to lack of increasing cell numbers the immobilized biomass failed to show decolorization at high concentration of dyes, which can be attributed to the lower observed decolorization efficiency in this case.

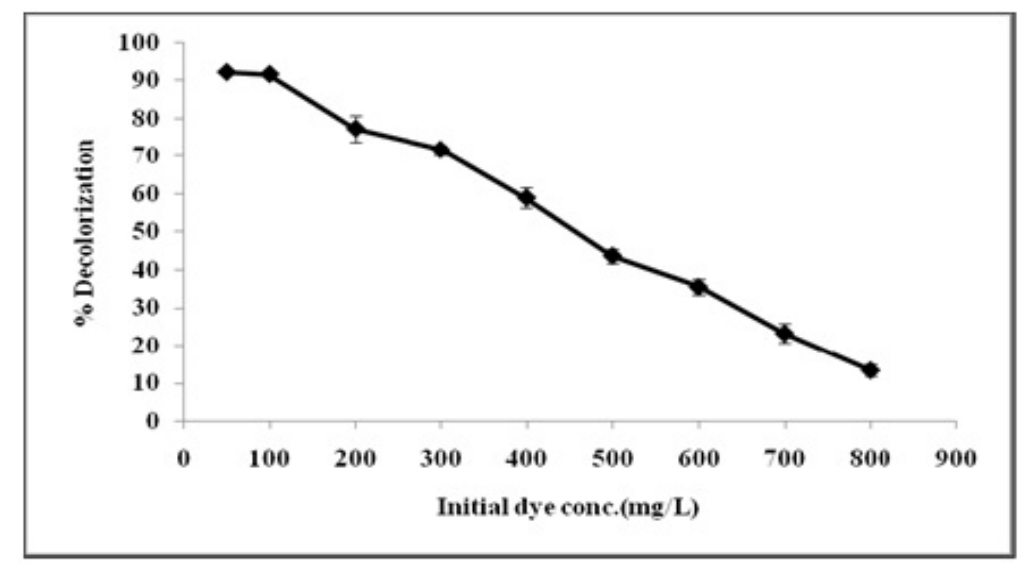

Figure 4. E ffect of initial dye concentrations on TPM dye decolorization

\section{Effect of exposure time on dye removal}

In order to study the effect of time on dye decolorizaion by immobilized bacterial cells the experiments were carried out at various dye concentrations at $\mathrm{pH} 7$, a temperature of $35^{\circ} \mathrm{C}$ and a shaking speed of $130 \mathrm{rpm}$. When studied, it was found that the immobilized cells of bacterial consortium was able to decolorize more than $90 \%$ of the dye from the solution when used in a concentration of $50 \mathrm{mg} / \mathrm{L}$ within $12 \mathrm{hr}$. No more decolorization was obtained after that. Good decolorization efficiency was also obtained in a dye concentration of $100 \mathrm{mg} / \mathrm{L}$ which also required $12 \mathrm{hr}$ to decolorize. It has been found that as the initial dye concentration increased the required time for decolorization also increased (Figure 5). Negligible decolorization was obtained in case of $800 \mathrm{mg} / \mathrm{L}$ and that was obtained after $24 \mathrm{hr}$ of incubation. It can be said that as dye concentrations increased more time is required by the immobilized biomass to decolorize such concentrated dye solutions. 


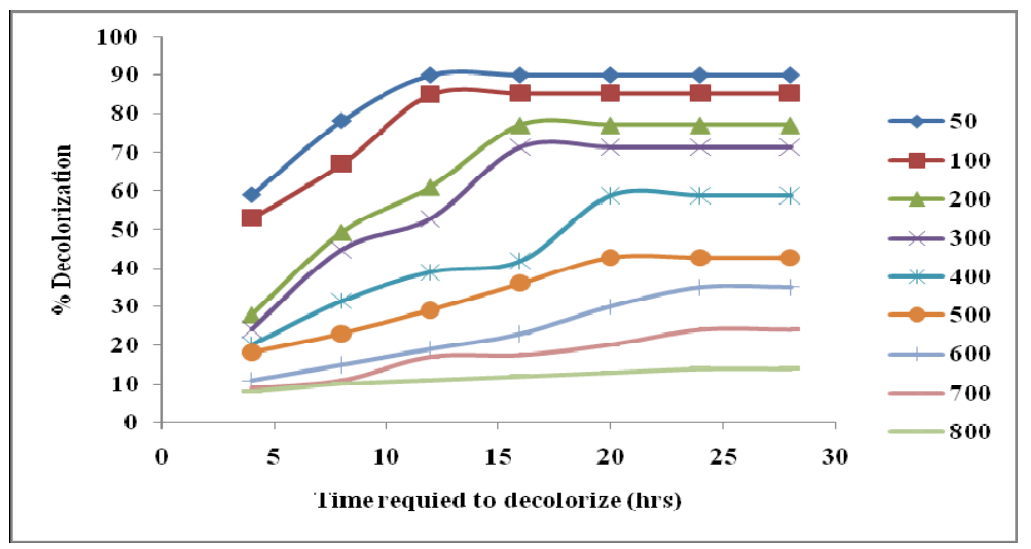

Figure 5. E ffect of exposure time on dye decolorization

\section{Effect of pH}

The experiment was performed in $100 \mathrm{ml}$ Erlenmeyer flasks containing $50 \mathrm{ml}$ dye mix containing Mineral salt medium where concentration of the dye was $50 \mathrm{mg} / \mathrm{L}$ at $35 \mathrm{C}$. The medium was inoculated approximately $1 \mathrm{gm}$ of immobilized beads which contains approximately $1 \times 10^{9}$ bacterial cells $/ \mathrm{ml}$ of bacterial culture. It was observed that the percentage of dye decolorization varied with change in $\mathrm{pH}$ of the medium (Figure 6). The decolorization rate peaked around $\mathrm{pH} 8$ within $24 \mathrm{hr}$; the organisms decolorized $92.5 \%$ of the dye from the medium. Additionally, the organisms also showed good decolorization efficiency at $\mathrm{pH} 7$ (90.2\%). Therefore, in the range of $\mathrm{pH}$ neutral to mild alkaline the immobilized organisms were proved to be an efficient decolorizer of triphenylmethane dyes. Most of these dyes found in the effluent are basic in nature. Therefore, in this case the immobilized consortium can be used effectively in case of treatment of industrial effluent.

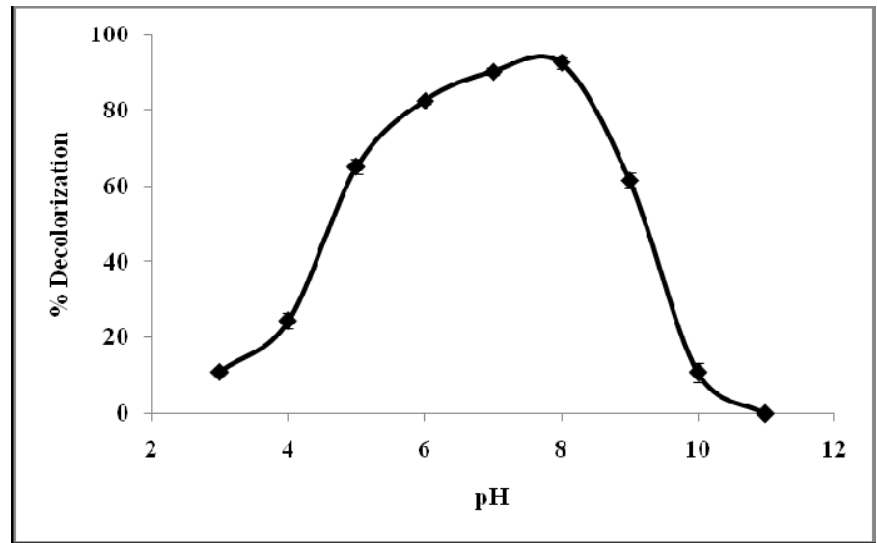

Figure 6. E ffect of $\mathrm{pH}$ on dye decolorization 


\section{Effect of temperature}

The immobilized organisms were capable of carrying out decolorization over a broad temperature range $\left(20-45^{\circ} \mathrm{C}\right)$. The optimum temperature for the removal of the dye was found to be $37^{\circ} \mathrm{C}$ (88.9\% dye decolorization) (Figure 7), good decolorization efficiency was obtained in range of 37- $40 \mathrm{C}$. This is a convenient temperature of most tropical countries during most of the time throughout the year, except for winter. Therefore, this ambient temperature could be considered as beneficial for dye industries to carry dye decolorization operations with immobilized biomass.

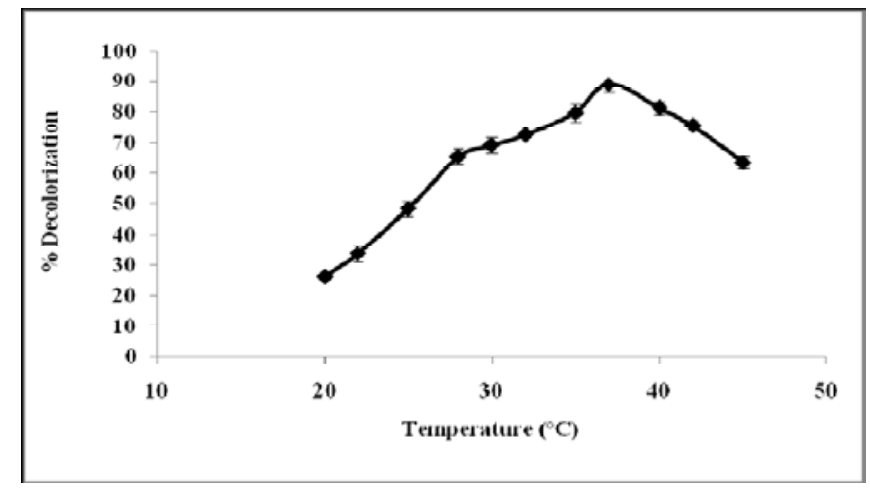

Figure 7. E ffect of temperature on dye decolorization

\section{Conclusion}

The present study confirms the effective decolorizing capacity of the bacterial biomass which was immobilized on calcium alginate matrix. Very few reports are available demonstrating the effectiveness of immobilized bacterial consortium as decolorizer of mixed triphenylmethane dyes. This study represents a suitable means by which triphenylmethane dye mix can be decolorized with the help of immobilized bacterial biomass. The most suitable condition for decolorization was also documented. The optimum conditions for removal of TPM dyes were found to be at $\mathrm{pH}$ 8 , temperature $37^{\circ} \mathrm{C}$, alginate concentration of $2 \%(\mathrm{w} / \mathrm{v})$, a cell concentration of $1 \times 10^{9}$ cells $/ \mathrm{ml}$. Maximum removal was obtained when dye concentration was $50 \mathrm{mg} / \mathrm{L}$ within $24 \mathrm{hr}$ of incubation.

\section{Acknowledgement}

The author is highly grateful to Scottish Church College authority and all staff members of Microbiology Department of Scottish Church College for their support and University Grant Commission for providing financial assistance to conduct the Minor Research Project under F.PSW-123/15-16 (ERO).

\section{Conflicts of interest}

The authors declare no conflicts of interest. 


\section{R eferences}

1. Gregory, P. 1993, Dyes and dyes intermediates. In: Encyclopedia of Chemical Technology Vol. 8 (Kroschwitz, J. I., Ed.). John Wiley \& Sons. New York, pp 544-545.

2. Azmi W., Sani R.K., and Banerjee U.C., 1998, “Biodegradation of Triphenylmethane dyes" Enzyme and Microbial Technology, 22, pp.185-191.

3. Willian, A. U., Pathak, S., Cheryl, J., and Hsu, T. C. 1978, "Cytogenic toxicity of Gentian Violet and Crystal Violet on mammalian cells in vitro”. Mutant. Res., 58, pp. 269-276.

4. Parshetti G., Kalme S., Saratale G. and Govindwar S., 2006. "Biodegradation of malachite green by Kocuria rosea MTCC 1532", Acta. Chim. Slov., 53, pp.492-498.

5. Culp S.J., Blankenship L.R., Kusewitt D.F., Doerge D.R., Mulligan L.T. and Beland F.A., 1999, "Toxicity and metabolism of malachite green and leucomalachite green during short-term feeding to Fischer 344 rats and B6C3F1 mice" Chem. Biol. Interact., 122, 3, pp 153-170.

6. Srivastava A.K., Sinha R., Singh N.D., Roy D., Srivastava S.J., 1995b,” Malachite green induced changes in carbohydrate metabolism and blood chloride levels in the freshwater catfish Heteropneustes fossilis" Acta Hydrobiol., 37, 2, pp 113-119.

7. Chen C.Y., Kuo J.T., Cheng C.Y., Huang Y.T., Ho I.H. and Chung Y.C., 2009, "Biological decolorization of dye solution containing malachite green by Pandoraea pulmonicola YC32 using a batch and continuous system", J. Hazard Mater. , 172, pp. 1439-1445.

8. Wu J., Jung B.G., Kim K-S, Lee Y-C and Sung N-C, 2009, "Isolation and characterization of Pseudomonas otitidis WL-13 and its capacity to decolorize triphenylmethane dyes "J. Environ. Sci., 21, pp. 960-964.

9. Pazarlioglu N.K., Urek R.O., Ergun F., 2005, "Biodecolourization of Direct Blue 15 by immobilized Phanerochaete chrysosporium”, Process Biochem., 40, pp.1923-1929.

10. Verma D.K. and Banik R.M. "Decolorization of triphenylmethane dyes using immobilized fungal biomass", ijrimsec.com/assoc_art/volume2/ijr13-4.pdf.

11. Charumathi D. and Das N., 2010." Removal of synthetic dye Basic Violet 3 by immobilized Candida tropicalis grown on sugarcane bagasse extract medium" IJEST, 2 (9), pp. 4325-4335.

12. Mukherjee T. and Das M. 2018, "Microbial decolorization of triphenylmethane dyes", IOSR-JBB, 4(2), pp.57-63.

13. Chheria J., Khaireddine M., Rouabhia M. and Bakhrouf A., 2012."Removal of Triphenylmethane Dyes by Bacterial Consortium". The Sci.World J. Article D 512454, pp 1-9.doi : $10.1100 / 2012 / 512454$.

14. Chen $\mathrm{K}-\mathrm{C}$, Wua $\mathrm{J}-\mathrm{Y}$, Huang $\mathrm{C}-\mathrm{C}$, Liang $\mathrm{Y}-\mathrm{M}$ and John Hwang $\mathrm{S}-\mathrm{C} .2003$, "Decolorization of azo dye using PVA-immobilized microorganisms" J. of Biotech., 101, pp 241252 